\title{
Proteomic changes in the xylem sap of Brassica napus under cadmium stress and functional validation
}

\author{
Jin-Song Luo ${ }^{1,2}$ and Zhenhua Zhang ${ }^{1,2^{*}}$
}

\begin{abstract}
Background: The xylem sap of vascular plants primarily transports water and mineral nutrients from the roots to the shoots and also transports heavy metals such as cadmium (Cd). Proteomic changes in xylem sap is an important mechanism for detoxifying Cd by plants. However, it is unclear how proteins in xylem sap respond to $\mathrm{Cd}$. Here, we investigated the effects of $\mathrm{Cd}$ stress on the xylem sap proteome of Brassica napus using a label-free shotgun proteomic approach to elucidate plant response mechanisms to $\mathrm{Cd}$ toxicity.

Results: We identified and quantified 672 proteins; 67\% were predicted to be secretory, and 11\% (73 proteins) were unique to $\mathrm{Cd}$-treated samples. Cd stress caused statistically significant and biologically relevant abundance changes in 28 xylem sap proteins. Among these proteins, the metabolic pathways that were most affected were related to cell wall modifications, stress/oxidoreductases, and lipid and protein metabolism. We functionally validated a plant defensin-like protein, BnPDFL, which belongs to the stress/oxidoreductase category, that was unique to the Cd-treated samples and played a positive role in Cd tolerance. Subcellular localization analysis revealed that BnPDFL is cell walllocalized. In vitro Cd-binding assays revealed that BnPDFL has Cd-chelating activity. BnPDFL heterologous overexpression significantly enhanced $\mathrm{Cd}$ tolerance in E. coli and Arabidopsis. Functional disruption of Arabidopsis plant defensin genes AtPDF2.3 and AtPDF2.2, which are mainly expressed in root vascular bundles, significantly decreased Cd tolerance.
\end{abstract}

Conclusions: Several xylem sap proteins in Brassica napus are differentially induced in response to Cd treatment, and plant defensin plays a positive role in Cd tolerance.

Keywords: Brassica napus, Cd stress, Label free, Proteomics, Xylem sap. Plant defensin

\section{Background}

Cadmium $(\mathrm{Cd})$ is a toxic non-essential element for plants. Plant vascular systems consist of xylem and phloem; their long-distance transport of various compounds allows plants to adapt to different environments [1-7]. The accumulation of $\mathrm{Cd}$ in a plant shoot is mainly determined by the plant's capacity to transport xylem sap long distances. Xylem sap is comprised of proteins, plant hormones, ions, and other molecules [7-12].

\footnotetext{
*Correspondence: zhzh1468@163.com

${ }^{1}$ Southern Regional Collaborative Innovation Center for Grain and Oil Crops in China, College of Resources and Environmental Sciences, Hunan Agricultural University, Changsha, China

${ }^{2}$ Hunan Provincial Key Laboratory of Farmland Pollution Control and Agricultural Resources Use, National Engineering Laboratory on Soil and Fertilizer Resources Efficient Utilization, Hunan Provincial Key Laboratory of Nutrition in Common University, Changsha 410128, China
}

Xylem sap proteomic research can be used to illustrate the impact of long-distance transport mechanisms in plants in response to $\mathrm{Cd}$ stress.

The long-distance transport of xylem sap is mainly driven by transpiration and root pressure [13]. Proteomic studies of xylem sap in many plant species have been reported over the past three decades [14-26]. Of the identified proteins, most are categorized as classical secretion proteins, and function annotation has revealed that they play important roles in plant growth, development, and stress responses [14-26]. With regards to stress responses, in one study, the xylem sap proteome changed in response to iron and manganese deficiencies in tomato (Solanum lycopersicum) [25], and in another, nitrogen under- and over-supply induced distinct protein responses in the xylem sap of maize [26]. 
Long-distance signaling allows plants to adapt to and survive severe environmental stress conditions. To adapt to drought stress, the root-derived CLE25 is secreted by the procambium of the xylem, transported from the roots to leaves where it is recognized by BAM1 and BAM3, then it upregulates the ABA biosynthesis gene, NCED3 and increases ABA accumulation, which in turn promotes stomatal closure in Arabidopsis [27]. Studies of the relay of C-TERMINALLY ENCODED PEPTIDE 1 (CEP1), CEP RECEPTOR 1 and 2 (CEPR1 and CEPR2), and CEP DOWNSTREAM (CEPD) have revealed that multiple layers of integration between local and systemic signals in roots and shoots orchestrate both the soil microenvironment and internal demand, thereby stimulating nitrate acquisition in nitrate-rich patches [28, 29]. However, it remains largely unknown how proteins change in response to Cd in xylem sap.

Proteomic change and long-distance transport from roots to shoots in xylem sap is an important mechanism for adapting to environmental stress [27-29]. Here, we investigate how Brassica napus plants respond to $\mathrm{Cd}$ via comprehensive analysis of proteomic changes in Brassica napus xylem sap, with the aim of elucidating plant response mechanisms to toxic $\mathrm{Cd}$ stresses. This study identifies many differentially-induced proteins in response to $\mathrm{Cd}$ treatment in the xylem sap of Brassica napus and functionally validates the hypothesis that plant defensins positively regulate $\mathrm{Cd}$ tolerance.

\section{Results}

Cadmium treatment affected Brassica napus seedling growth and physiological traits

Brassica napus plants (2 weeks-old), hydroponically grown with $10 \mu \mathrm{M} \mathrm{Cd}$, showed serious symptoms 3 days after treatment. At sampling time (Day 17), a marked chlorosis was observed on younger leaves (Fig. 1a, b). The average leaf chlorophyll concertation in these plants (21.4) was significantly lower than that measured in the control plants (29.9) (Fig. 1c). Plant fresh weight significantly decreased after Cd treatment (Fig. 1d). Accordingly, the concentrations of $\mathrm{Cd}$ determined by ICP-MS in the shoot and xylem sap of $\mathrm{Cd}$ treated plants were $206 \mu \mathrm{g} / \mathrm{g}$ dry weight and $4.3 \mathrm{mg} / \mathrm{L}$ respectively (Fig. 1e and $\mathrm{f}$ ).

\section{Brassica napus xylem sap proteins detected by Coomassie blue staining}

We obtained 15-20 ng/ $\mu \mathrm{l}$ protein from Brassica napus xylem sap using the root pressure method. SDS-PAGE analysis of xylem sap $(15 \mu \mathrm{l})$ followed by Coomassie blue staining revealed different protein compositions in these saps (Fig. 2). The protein molecular weights ranged from approximately 14 to $116 \mathrm{kd}$. Cd significantly increased

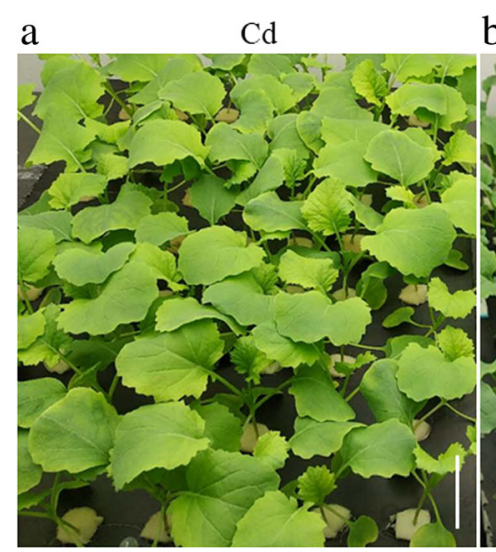

b $\quad \mathrm{CK}$

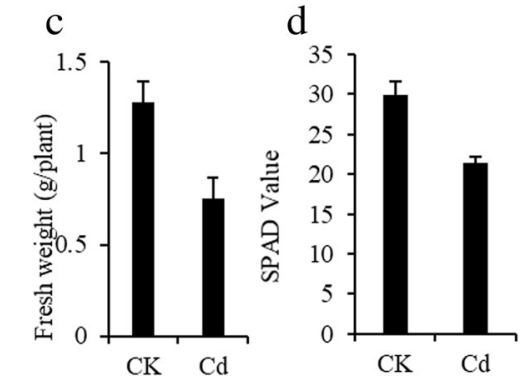

d

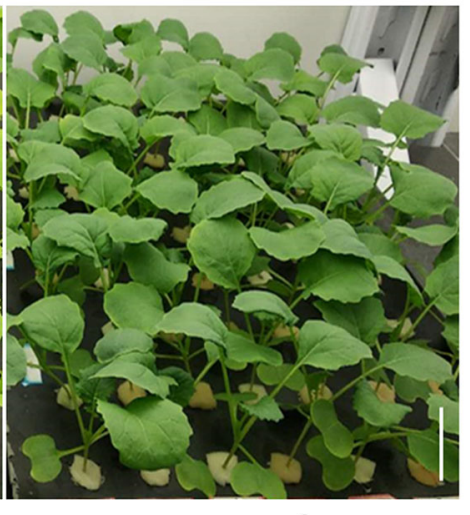

$\mathrm{e}$
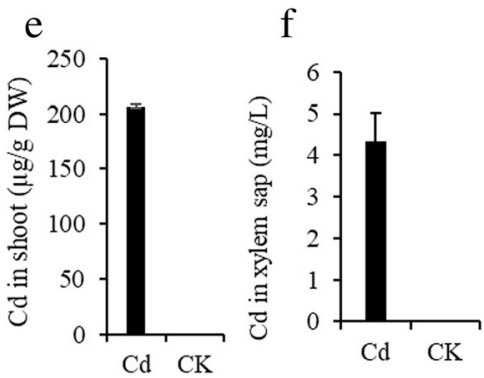

Fig. 1 Physiological effects of Cd-addition to hydroponic Brassica napus plants. Brassica. napus cultivar 'Xiang-you 15' ('XY15') seedlings were hydroponically cultivated. At 2 weeks of age, the hydroponically grown Brassica napus seedlings were exposed to a 10 and $\mathbf{b} 0 \mu \mathrm{M} C \mathrm{Cd}$. After three days, $\mathbf{c}$ fresh weight, $\mathbf{d}$ SPAD value and $C d$ in $\mathbf{e}$ shoots and $\mathbf{f}$ xylem sap were determined. Scale bars, $5 \mathrm{~cm}$. Data are mean $\pm S D, n=5$ 


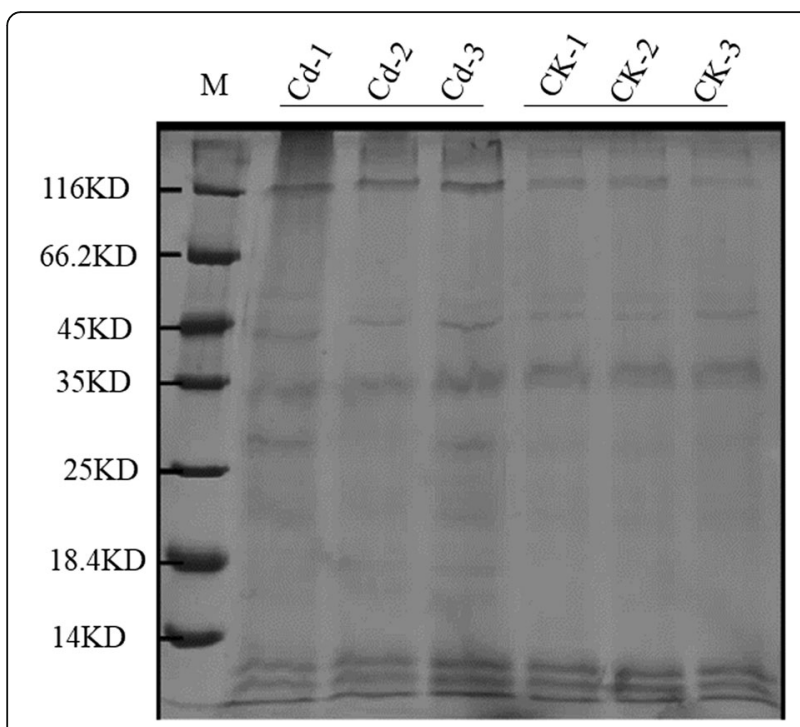

Fig. 2 Separation of xylem sap proteins by SDS-PAGE. Proteins from the xylem sap were concentrated then separated by SDS-PAGE. The gel was stained with Coomassie brilliant blue. $\mathrm{M}$ are protein molecular mass markers (kDa). CK-1, CK-2, CK-3, Cd-1, Cd-2, and Cd-3 represent biological replicates xylem sap samples from control and Cd-treated Brassica napus plants respectively

protein abundance at $116 \mathrm{kd}$ (Fig. 2). To identify proteins in these samples that are below the limit of detection by Coomassie blue staining, we utilized the 'shotgun analysis' proteomic method.

\section{Identification of xylem sap proteins}

In-solution digestion was carried out to determine the protein contents of xylem sap samples from control and Cd-treated Brassica napus plants (CK-1, CK-2, CK-3, and $\mathrm{Cd}-1, \mathrm{Cd}-2$, and $\mathrm{Cd}-3$, respectively) (Additional file 1). The LC-MS/MS analysis detected 672 proteins in the Brassica napus xylem sap, 460 proteins in the CK samples, and 468 in the Cd-treated samples (Table 1). Of the 672 proteins, 244 were reliably identified and quantified with at least two peptides.

Bioinformatics analysis with the web tool TargetP and SecretomeP among the identified proteins revealed that 450 of the 672 identified and quantified proteins (67\%) belong to the secretory pathway. Among these secretory proteins, 282 (42\% of the total identified in the xylem sap) were classified as classical secretory proteins (CS), those containing secretion signal peptides, whereas 168 (25\%) were classified as non-classical secretory proteins (NCS). The remaining 222 proteins (33\%) were predicted to be non-secretory proteins (NS) (Additional file 2).

Of the proteins identified in at least two independent samples, 268 were found in both control and Cd-treated samples, 50 were unique to control samples, and 73 were unique to $\mathrm{Cd}$-treated samples (Additional file $3 \mathrm{a}$ ). For the xylem sap proteins of the control plants, shotgun label free LC-MS/MS proteomic analysis identified 229, 321 and 373 plant proteins from CK-1, CK-2 and CK-3, respectively, and 400, 388 and 414 plant proteins from $\mathrm{Cd}-1, \mathrm{Cd}-2$ and $\mathrm{Cd}-3$, respectively (Table 1 ). Among these, 145 proteins were common among the control plants (63.3\% of CK-1, $45.2 \%$ of CK-2 and $38.9 \%$ of CK3 ), and 331 proteins were common among the $\mathrm{Cd}$ treated plants $(82.8 \%$ of $\mathrm{Cd}-1,85.3 \%$ of $\mathrm{Cd}-2$, and $80.0 \%$ of Cd-3) (Additional file $3 \mathrm{~b}, \mathrm{c}$ ). Differences in the number of proteins identified in the xylem sap samples between the control and Cd-treated samples could be due to Cd stress.

The molecular masses of the Brassica napus xylem sap plant proteins ranged from $1.5 \mathrm{kDa}$ (A0A078JEE5, Uncharacterized protein) to $228.4 \mathrm{kDa}$ (A0A078F4P9, Uncharacterized protein). However, the majority of plant proteins $(90 \%)$ had molecular masses between 5 and 50 $\mathrm{kDa}$ (Additional file $4 \mathrm{a}$ ), which coincided with the band

Table 1 Proteins identified using label-free shotgun analyses in the xylem sap of Brassica napus

\begin{tabular}{lcc}
\hline Database & Sample & Proteins number \\
\hline Uniport-Brassica-naps & $\mathrm{Cd}-1$ & 400 \\
Uniport-Brassica-naps & $\mathrm{Cd}-2$ & 388 \\
Uniport-Brassica-naps & $\mathrm{Cd}-3$ & 414 \\
Uniport-Brassica-naps & $\mathrm{CK}-1$ & 229 \\
Uniport-Brassica-naps & $\mathrm{CK}-2$ & 321 \\
Uniport-Brassica-naps & $\mathrm{CK}-3$ & 373 \\
Uniport-Brassica-naps & Total & 672 \\
\hline
\end{tabular}


patterns observed in the one-dimensional SDS-PAGE (Fig. 2). These results suggest that Brassica napus xylem sap proteins mainly consist of relatively small sized proteins. The average andromeda score for Brassica napus xylem sap plant proteins was 89.55 and most of the identified proteins $(88 \%)$ had an andromeda score greater than 60 (Additional file $4 \mathrm{~b}$ ). The peptide coverage distribution of Brassica napus xylem sap plant proteins ranged from 1 to $90 \%$, while the identified peptide length distribution of Brassica napus xylem sap plant proteins ranged from 7 to 33 amino acid residues (Additional file $4 \mathrm{c}, \mathrm{d}$ ).

\section{Effect of cd treatment on the xylem sap proteome}

$\mathrm{Cd}$ treatment caused statistically significant (ANOVA, $p \leq$ 0.05 ) and biologically relevant (fold $\geq 2$ or fold $\leq 0.5$ ) changes in 28 proteins (Fig. 3). Among them, 12 proteins showed significant increases (fold change $\geq 2$ in Table 2) and of these, 9 were classified as secretory (8 CS and 1 NCS). The remaining three proteins were classified as non-secretory proteins (Table 2). Based on the functional classification of the 12 proteins that increased in abundance, stress/oxido-reductases and protein synthesis metabolism were the most represented categories (Table 2). Remarkable increases in abundance (greater than 20-fold) were observed in two proteins: one cysteine-rich secretory protein, Antigen 5, that belongs to the pathogenesisrelated 1 protein superfamily protein (A0A078IA81) and one osmotin-like protein (A0A078GFP1). These data will be useful for identifying candidate genes for further study.

$\mathrm{Cd}$ treatment caused relative decreases in the abundance of 16 proteins (fold change $<0.5$ in Table 2), and from these 11 were classified as secretory proteins (9 CS and 2 NCS). The remaining 5 proteins were classified as non-secretory proteins. Functional classification of the 16 proteins that decreased in abundance showed that cell wall modification, lipid metabolism and protein metabolism were the most represented categories (Table 2). Most increases were moderate, ranging between 2- and 3 -fold, but remarkable decreases in abundance (higher than 14-fold) were observed in two proteins: a photosystem II reaction center protein L(D1L8Q3) and an Arabidopsis thaliana dirigent protein 6-like protein (A0A078HCG2).

Among the 672 proteins identified in the xylem sap, 73 proteins were unique to the $\mathrm{Cd}$-treated plants and from these, 46 were classified as secretory (26 CS and 20 NCS). The remaining 27 proteins were classified as nonsecretory proteins. Functional classification of the 46 secretory proteins revealed that cell wall metabolism, stress/oxido-reductase, protein synthesis/degradation and carbohydrate metabolism proteins were the most represented categories (Table 3). These proteins may specifically regulate $\mathrm{Cd}$ stress responses.

\section{Defensin-like proteins in Brassica napus xylem sap}

We identified two proteins in Brassica napus xylem sap that were similar to the rice defensin-like proteins CAL1 that play important roles in $\mathrm{Cd}$ efflux and allocation [30]. The related peptides that we identified could be clearly mapped to the products of two different genes of this family based on their amino acid sequences (Fig. 4a) . We examined the expression patterns of genes for the defensin-like proteins detected in xylem sap using RNA sequences from roots and leaves of Brassica napus plants. The mRNAs for these proteins were distributed mainly in Brassica napus leaves (Fig. 4b). The relative expression of BnaA07g32150D and BnaC02g23620D in leaves and roots were unaffected by $\mathrm{Cd}$ treatment. We used BnaC02g23620D, named BnFDEL and uniquely present in the Cd-treated xylem sap, for further functional validation.

\section{Functional identification of $B n P D F L$ in vitro}

Bioinformatics analysis showed that BnPDFL encodes a defensin family protein of 85 amino acids, consisting of a cysteine-rich domain and a secretion signal peptide. The probable signal peptide cleavage site is between position 25 and 26 amino acids (Additional file 5 a). The amino acid sequences BnPDFL are not similar to those of PDF proteins from other plants (Additional file $5 \mathrm{~b}$ ). Metal binding assays were performed using purified fusion protein from $E$. coli transformants treated with $100 \mu \mathrm{M} \mathrm{CdCl}{ }_{2}$ as described [31]. An $\triangle \mathrm{SpBnPDFL} / \mathrm{Cd}$ molar ratio of $\sim 1$ was detected for the $\triangle$ SpBnPDFL fusion protein (Fig. 5a). Heterologous overexpression of $\triangle S p B n P D F L$ enhanced Cd tolerance in E. coli (Fig. 5b), while it had no effect on $\mathrm{Cd}$ accumulation (Fig. 5c), consistent with the model indicating that BnPDFL mediated the chelation of $\mathrm{Cd}$ to enhance $\mathrm{Cd}$ tolerance.

\section{Heterologous overexpression of BnPDFL enhanced cd tolerance in Arabidopsis}

Our previous study suggested that defensin-like gene mediates cadmium tolerance or accumulation [30-32]. To examined the effect of heterologous overexpressing $B n P D F L$ on metal tolerance in Arabidopsis, we transformed Arabidopsis with construct BnPDFL-mRFP driven by the $35 \mathrm{~S}$ promoter. Subcellular localization assay revealed that BnPDFL is a cell wall localized protein (Additional file 6). When germinated without heavy metals, the growth of overexpression lines $\mathrm{OE}-5$ and OE-8 was similar to that of the wild-type Col-0 (Fig. 6a). However, when germinated on $50 \mu \mathrm{M} \mathrm{CdCl}_{2}$, lines $\mathrm{OE}-5$ and OE-8 grew longer roots than did the wild-type control (Fig. 6b). However, no significant differences were observed in shoot and root $\mathrm{Cd}$ levels between wild-type Col-0 and overexpression lines (Fig. 6c). These data 
a
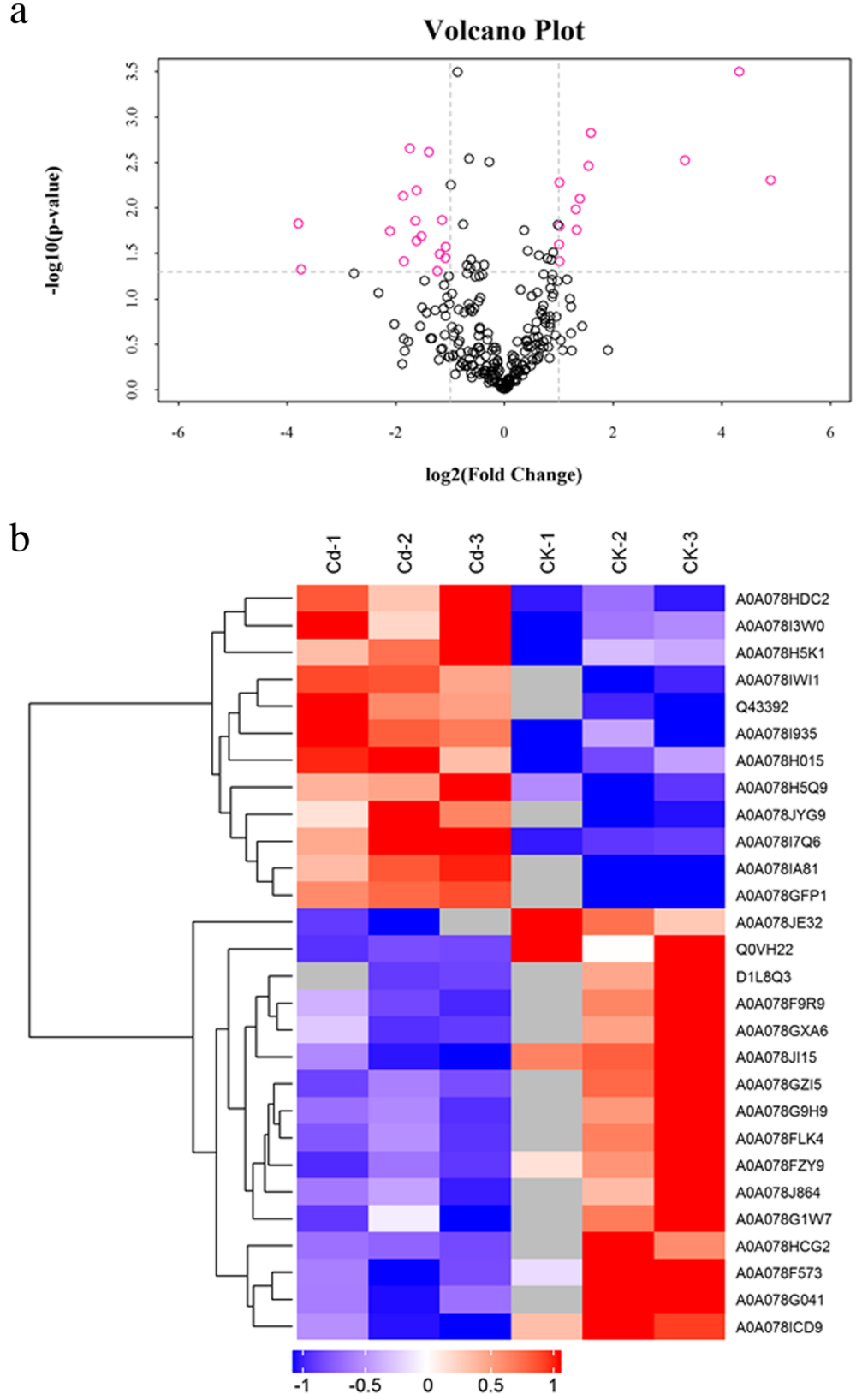

Fig. 3 Effect of $\mathrm{Cd}$ on the xylem protein profile as revealed by label-free shotgun analyses. At two weeks of age, the hydroponically grown Brassica napus seedlings were exposed to 0 and $10 \mu \mathrm{M}$ of $\mathrm{Cd}$ for three days. a Volcano scatter plot showing the identified and quantified proteins in xylem sap. Proteins unaffected by $\mathrm{Cd}$ are depicted in black, and proteins changing as a result of Cd (ANOVA, $p \leq 0.05)$ are depicted in red (left represents decreasing, right represents increasing). b Cluster of proteins controlled by Cd (ANOVA $p<0.05)$. Heatmaps report high (red) and low level (blue). CK-1, CK-2, CK-3, Cd-1, Cd-2, and Cd-3 represent biological replicates xylem sap samples from control and Cd-treated Brassica napus plants respectively

indicated that heterologous overexpression of BnPDFL enhanced Cd tolerance in Arabidopsis.

\section{Functional disruption of plant defensin decreased cd tolerance in Arabidopsis}

To further show that plant defensin plays a positive role in $\mathrm{Cd}$ tolerance, we generated two homozygous knockout mutants of plant defensin AtPDF2.2 and AtPDF2.3 using clustered regularly interspaced short palindromic repeats/ associated protein 9 (CRISPR/Cas9) technology (Fig. 7a). To clarify the expression pattern of AtPDF2.2 and AtPDF2.3, we generated AtPDF2.2 and AtPDF2.3 promoter-driven GUS transgenic Arabidopsis. AtPDF2.3 promoter-driven GUS signals were detected in root and 
Table 2 Proteins that significantly changed in abundance among the identified proteins affected by Cd (ANOVA, $p \leq 0.05$ and fold $\geq 2$ or $\leq 0.5)$

\begin{tabular}{|c|c|c|c|c|c|c|}
\hline Accession $^{a}$ & Similar to Arabidopsis & is Description & Secretome $\mathrm{P}^{b}$ & $\mathrm{Pep}_{\mathrm{Cd}} / \mathrm{Pep}_{\mathrm{CK}}$ & $\begin{array}{c}\text { Fold change } \\
\mathrm{Cd}^{\prime} \mathrm{CK}^{c}\end{array}$ & $\begin{array}{l}\text { Functional } \\
\text { classification }\end{array}$ \\
\hline A0A078IWI1 & AT4G08770 & Peroxidase 37 & $\mathrm{CS}$ & $2 / 2$ & 9.9 & \multirow{6}{*}{$\begin{array}{l}\text { Stress/oxido- } \\
\text { reductases }\end{array}$} \\
\hline A0A078I7Q6 & AT4G33420 & Peroxidase superfamily protein & CS & $7 / 7$ & 3.0 & \\
\hline A0A078IA81 & AT4G33720 & $\begin{array}{l}\text { Cysteine-rich secretory proteins, Antigen } 5 \text {, and } \\
\text { pathogenesis-related } 1 \text { protein superfamily protein }\end{array}$ & $\mathrm{CS}$ & $2 / 2$ & 29.6 & \\
\hline A0A078GFP1 & AT4G11650 & Osmotin-like protein & CS & $2 / 2$ & 20.0 & \\
\hline A0A078I3W0 & AT2G43620 & Chitinase family protein & CS & $9 / 9$ & 2.0 & \\
\hline Q43392 & AT2G14580 & Basic pathogenesis-related protein & CS & $1 / 1$ & 2.0 & \\
\hline \multirow{2}{*}{$\begin{array}{l}-\mathrm{A} 0 \mathrm{~A} 078 \mathrm{HDC} 2 \\
\mathrm{~A} 0 \mathrm{~A} 0781935\end{array}$} & $2 \ldots$ AT1G78 860 & _Low_boron tolerance & CS & $-3 / 3$ & 2.6 & \multirow{2}{*}{$\begin{array}{l}\text { Lipid } \\
\text { metabolism }\end{array}$} \\
\hline & AT5G55450 & Bifunctional inhibitor/lipid-transfer protein & $\mathrm{CS}$ & $1 / 1$ & 2.9 & \\
\hline $\mathrm{A} 0 \mathrm{~A} 078 \mathrm{H} 5 \mathrm{~K} 1$ & AT5G57870 & $\begin{array}{l}\text { - /seed storage } 2 \text { s albumin superfamily protein } \\
\text { Eukaryotic translation initiation factor isoform } 4 \mathrm{~g} 1\end{array}$ & $\mathrm{NS}$ & $\overline{1} / \overline{1}$ & 2.0 & \multirow{4}{*}{$\begin{array}{l}\text { Protein } \\
\text { metabolism }\end{array}$} \\
\hline A0A078H015 & AT1G09690 & Translation protein SH3-like family protein & NCS & $\begin{array}{l}1 / 1 \\
3 / 3\end{array}$ & $\begin{array}{l}2.0 \\
2.4\end{array}$ & \\
\hline _ & AT1 1 G692 10 & _Eukaryotic elongation factor $5 \mathrm{~A}-3$ & NS & $-1 / 1$ & 2.0 & \\
\hline A 0 A 078 H 59 & AT $5 \underline{G} 49460$ & ATP_citrate lyase subunit b 2 2 & NS & $-\underline{3} / \underline{3}$ & 2.5 & \\
\hline $\mathrm{A} 0 \mathrm{~A} 078 \mathrm{JE} 32$ & $\mathrm{AT} 5 \mathrm{G} 03170$ & Encodes FLA11. & $\mathrm{CS}^{-}$ & $2 / 2$ & 0.32 & \multirow{6}{*}{$\begin{array}{l}\text { Cell wall } \\
\text { metabolism }\end{array}$} \\
\hline A0A078F9R9 & AT5G13870 & EXGT-A4, endoxyloglucan transferase & $\mathrm{CS}$ & $1 / 1$ & 0.34 & \\
\hline A0A078GZI5 & AT2G27860 & UDP-D-apiose/UDP-D-xylose synthase 1 & NS & $1 / 1$ & 0.32 & \\
\hline A0A078G9H9 & AT5G61250 & Belongs to the plant glycoside hydrolase family 79 & CS & $1 / 1$ & 0.34 & \\
\hline A0A078HCG2 & AT4G23690 & Arabidopsis thaliana dirigent protein 6 & $\mathrm{CS}$ & $5 / 5$ & 0.07 & \\
\hline A0A078F573 & AT4G23690 & $\begin{array}{l}\text { Encodes a homodimeric all-beta dirigent protein } \\
\text { in the superfamily of calycins }\end{array}$ & NS & $1 / 1$ & 0.43 & \\
\hline A0A078GXA6 & AT1G09560 & GERMIN-LIKE PROTEIN 5 & CS & $1 / 1$ & 0.27 & \multirow{3}{*}{$\begin{array}{l}\text { Lipid } \\
\text { metabolism }\end{array}$} \\
\hline$\overline{\mathrm{A}} \overline{0} \overline{\mathrm{A}} 0 \overline{\mathrm{N}} \overline{\mathrm{F}} \overline{\mathrm{Z}} \overline{\mathrm{Y}} \overline{9}$ & $\mathrm{AT} 2 \mathrm{G} 10940$ & $\begin{array}{l}\text { Bifunctional inhibitor/lipid-transfer protein } \\
\text { seed storage } 2 \mathrm{~S} \text { albumin superfamily protein }\end{array}$ & $\overline{\mathrm{CS}}$ & $\overline{1} / \overline{1}$ & $0 . \overline{4} \overline{7}$ & \\
\hline A0A078ICD9 & AT1G62790 & Bifunctional inhibitor/lipid-transfer protein/ & $\mathrm{CS}$ & $1 / 1$ & 0.274 & \\
\hline \multicolumn{2}{|c|}{ D1L8Q23 } & $\begin{array}{l}\text { seed storage 2S albumin superfamily protein } \\
\text { Photosystem II reaction center_protein L }\end{array}$ & 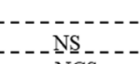 & $1 / 1$ & -0.07 & - - - - - - - - - - - \\
\hline $\mathrm{A} 0 \mathrm{~A} 078 \mathrm{~J} 15$ & AT $1 \mathrm{G} 27310$ & Nuclear transport factor $2 \mathrm{~A}$ & $\mathrm{NCS}$ & $2 / 2$ & 0.38 & \multirow{3}{*}{$\begin{array}{l}\text { Protein } \\
\text { metabolism }\end{array}$} \\
\hline A0A078FLK4 & AT4G39200 & Ribosomal protein S25 family protein & NS & $2 / 2$ & 0.45 & \\
\hline A0A078J864 & AT4G16720 & Ribosomal protein L23/L15e family protein & NS & $2 / 2$ & 0.42 & \\
\hline _ $-\underline{A} \underline{0} \underline{A} 078-\underline{G} 04 \underline{1}$ & 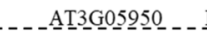 & RmlC-like cupins superfamily_protein_ & $\underline{C}$ & $-4 / 4$ & 0.30 & \multirow{3}{*}{$\begin{array}{l}\text { Stress/oxido- } \\
\text { reductases }\end{array}$} \\
\hline QOVH 22 & AT1G08830 & Superoxide dismutase 1 & NCS & $2 / 2$ & 0.23 & \\
\hline A0A078G1W7 & AT5G66590 & $\begin{array}{l}\text { Cysteine-rich secretory proteins, Antigen } 5 \text {, and } \\
\text { pathogenesis-related } 1 \text { protein superfamily protein }\end{array}$ & $\mathrm{CS}$ & $3 / 3$ & 0.47 & \\
\hline
\end{tabular}

${ }^{a}$ Accession indicates protein UniProt database entry

${ }^{b}$ The SecretomeP column indicates results from subcellular classification. $C S=$ Classical secretory proteins, NCS $=$ non-classical secretory proteins, NS = non-secretory proteins

$\mathrm{Pep}_{\mathrm{Cd}} / \mathrm{Pep}_{\mathrm{CK}}$ indicates the number of peptides assigned to a protein and number of peptides used for quantification

${ }^{c}$ Abundance changes (Fold Cd/control) were calculated by dividing the relative mean abundances in mean Cd by that of the control samples (mean control)

shoot vascular bundles (Additional file 7 a, b), while AtPDF2.2 promoter-driven GUS signals were detected mainly in root vascular bundles, root hairs and cotyledons (Additional file $7 \mathrm{c}, \mathrm{d}$ ). The seedling metal tolerance assay result obviously showed that the roots of the $p d f 2.3$ and pdf2.2 mutants were more sensitive to $\mathrm{Cd}$ compared with wild-type Col-0 (Fig. 7b, c). While no significant differences were detected in shoot and root $\mathrm{Cd}$ concertation between wild-type Col-0, $p d f 2.3$ and $p d f 2.2$ mutants (Fig. $7 \mathrm{~d}$ ) . These results further confirmed that plant defensin conveyed $\mathrm{Cd}$ tolerance.

\section{Discussion}

The proteomic approach used in this study identified and quantified 672 proteins in the xylem sap of Brassica napus, which is considerably higher than the 69 proteins previously identified in 2-DE [6], though a recent study found 643 proteins in tomato xylem sap using a similar shotgun method [25], indicating that the shotgun labelfree analysis used in this study is very sensitive. Our results showed that nearly $67 \%$ of the identified xylem proteins were classified as secretory and 33\% were identified as non-secretory, which could in part be due to cytoplasmic contamination. The relatively high percentage of non-secretory proteins observed here may also be due to the high sensitivity of the LC-MS/MS approach utilized, and their secretory mechanisms in the xylem sap proteome require further studies.

The plant cell has evolved many mechanisms to defend itself against $\mathrm{Cd}$ toxicity. Cell walls represent the most important physical and chemical barriers to prevent $\mathrm{Cd}$ from entering and damaging the protoplast [33]. The plant cell wall consists of primary and secondary cell walls and both have an array of detoxification mechanisms to cope with $\mathrm{Cd}$ stress. Pectin is the major component of primary cell walls, containing most of the negative charges, and it can sequester $\mathrm{Cd}$. In the secondary cell wall, lignification can prevent $\mathrm{Cd}$ from entering and damaging the cell $[33,34]$. The molecular mechanisms of cell wall responses to $\mathrm{Cd}$ stresses remain unknown. Here, we identified several proteins involved in cell wall metabolism that significantly changed in the xylem sap of Cd-treated plants: A0A078JE32, A0A078F9R9, A0A078GZI5, A0A078G9H9, A0A078HCG2, A0A078F573 and A0A078GXA6 significantly decreased under $\mathrm{Cd}$ stress (Table 2), while the methyl pectin enzyme A0A078JU82 was identified only in 
Table 3 List of identified proteins unique to Cd-treated xylem sap samples from Brassica napus

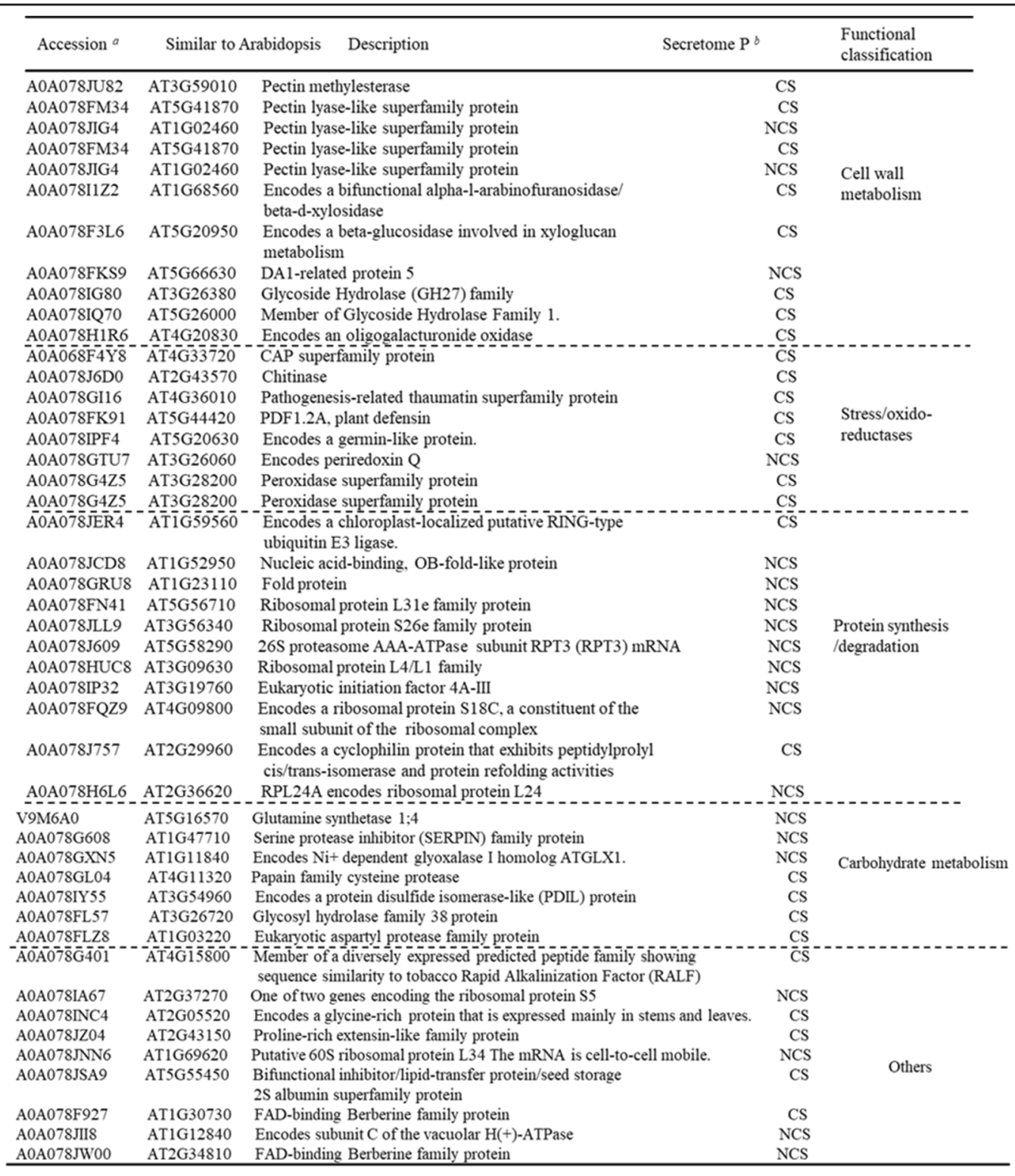

${ }^{a}$ Accession indicates protein UniProt database entry

${ }^{b}$ The SecretomeP column indicates results from subcellular classification. $C S=$ Classical secretory proteins, $N C S=$ non-classical secretory proteins

the xylem sap of the Cd-treated plants (Table 3). Xylem vascular tissue and the cell wall are part of the apoplast, and xylem parenchyma cells and cell wall localized proteins may be transported through the apoplast pathway to the xylem sap like CAL1 [30]. Homologues of these proteins have been associated with cell metabolism that mediates abiotic stress response in Arabidopsis [34-38]. Our results indicated that the plant cell wall plays an important role in $\mathrm{Cd}$ detoxification and accumulation, and we identified many candidate genes for further study.

Cadmium can induce the production of plant reactive oxygen species that are harmful to plant cells via indirect mechanisms [39], and it is important to maintain cellular redox balance. Previous studies revealed that antigen 5 and pathogenesis-related 1 protein (CAP) superfamily negatively regulate salt-stress tolerance in Arabidopsis [40]. Here, the CAP/oxido-reductase related proteins A0A078IWI1, A0A078I7Q6, A0A078IA81, A0A078GFP1, A0A078I3W0, Q43392 and A0A078HDC2 significantly increased and Q0VH22 and A0A078G1W7 decreased under Cd stress in Brassica napus xylem sap (Table 2). This suggests that the antioxidant defense system attempted to restore a disturbed redox balance.

The long-distance root-to-shoot transport of phytochelatins mediate $\mathrm{Cd}$ tolerance and accumulation in 
a

\begin{tabular}{cll}
\hline Gene ID & \multicolumn{1}{c}{ Peptide sequence } & Description \\
\hline BnaA07g32150D & SSGTWSGVCGNNNACK & Defensin-like protein \\
& LEGAQHGSCNYVFPAHK & \\
BnaC02g23620D & CNNAVPTPK & Defensin-like protein
\end{tabular}

b
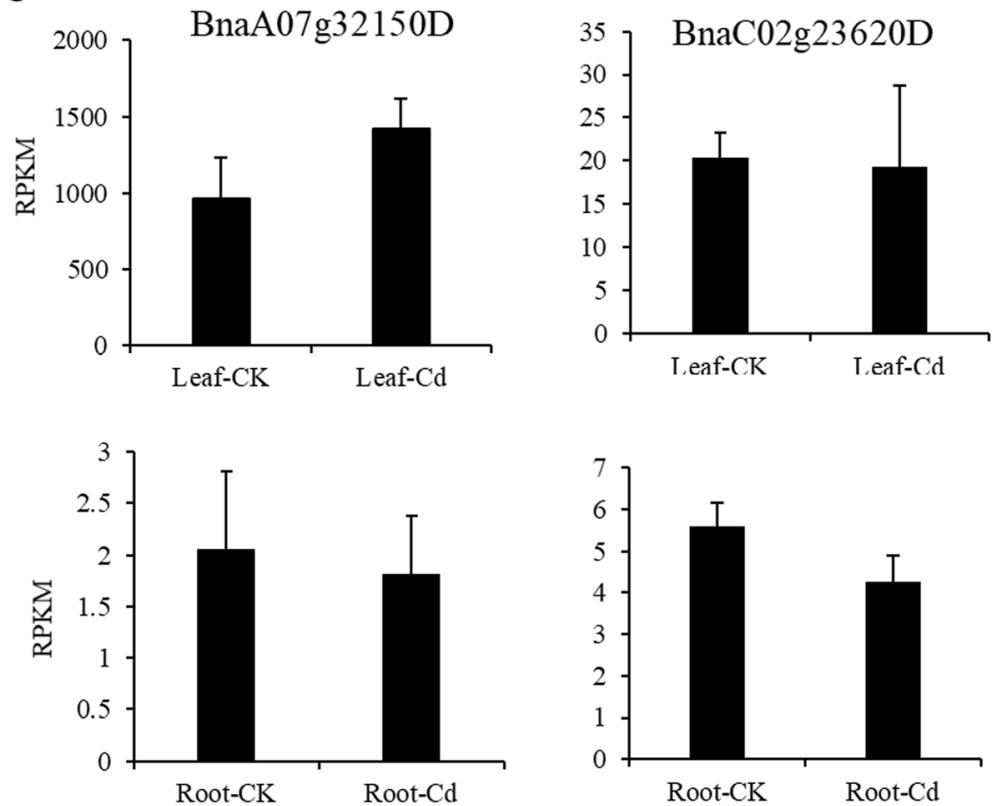

Fig. 4 Defensin-like proteins identified in in the xylem sap of Brassica napus and expression. a Two defensin-like proteins were identified in the xylem sap of Brassica napus by LC-MS/MS. b The expression levels of two defensin-like genes in Brassica napus leaves and roots based on RNA sequencing. At two weeks of age, the hydroponically grown Brassica napus seedlings were exposed to 0 and $10 \mu \mathrm{M}$ of $\mathrm{Cd}$ for three days. Data are mean $\pm \mathrm{SD}, n=3$
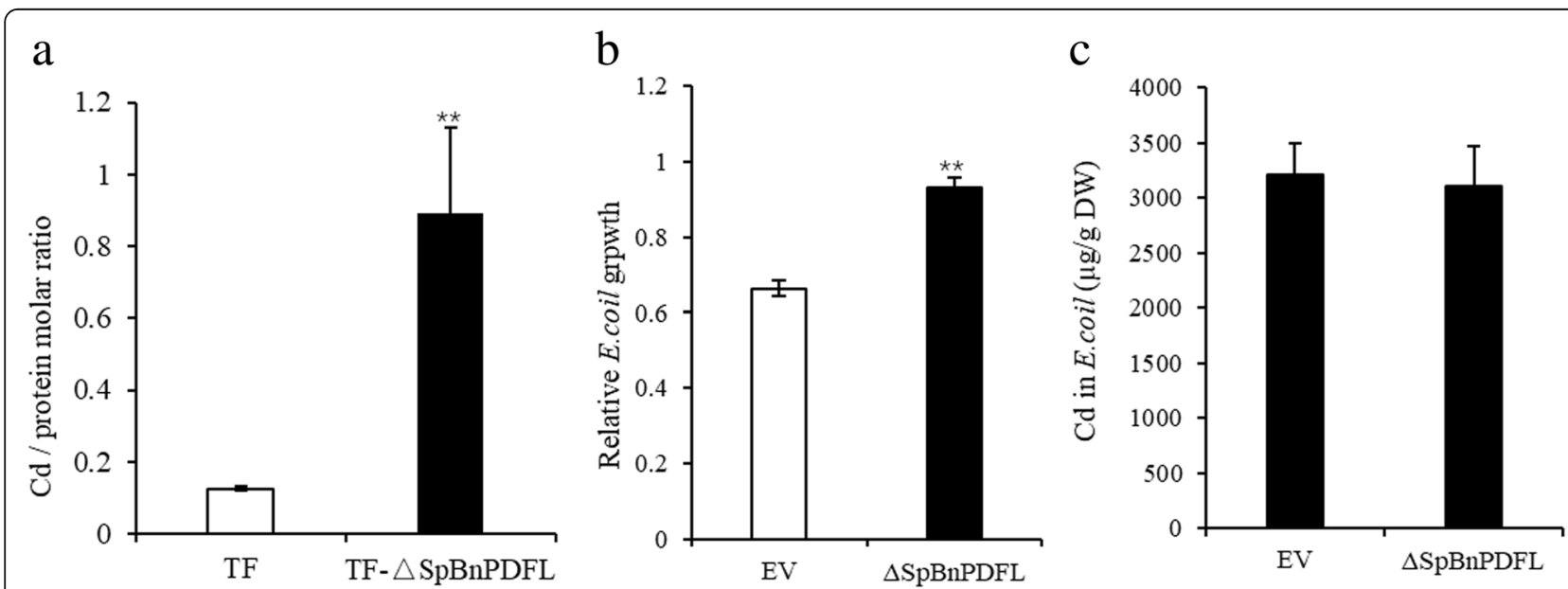

Fig. 5 In vitro $C d$ binding, tolerance and accumulation assay of $\triangle S P B n P D F L$ in $E$. coli. a In vitro $C d$ binding assay. TF represents the $E$. coli trigger factor protein that fused to the N-terminus of target proteins, and the secretion signal peptide (SP)-deleted BnPDFL (TF- $\triangle$ SpBnPDFL) were used to transform $E$. coli. The molar ratio of $C d$ against TF- $\triangle S$ SpBnPDFL protein purified from E. coli cells grown with $100 \mu \mathrm{M} \mathrm{CdCl}_{2}$ for $10 \mathrm{~h}$ was determined by ICP-MS. $\mathbf{b}$ Heterologous overexpression of $\triangle S P B n P D F L$ enhanced $C d$ tolerance in $E$. coli. Relative growth rates for $E$. coli strains expressing empty vector or $\triangle$ SpBnPDFL supplemented with 0,200 $\mu \mathrm{M} \mathrm{CdCl}_{2}$ for $6 \mathrm{~h}$. $\mathbf{c ~ C d}$ concentration in $E$. coli strains from (b) was determined by ICP-MS. Data are mean \pm $\mathrm{SD}, n=4$. Significant differences were determined by Student's t-test $\left({ }^{* *} P<0.01\right)$ 


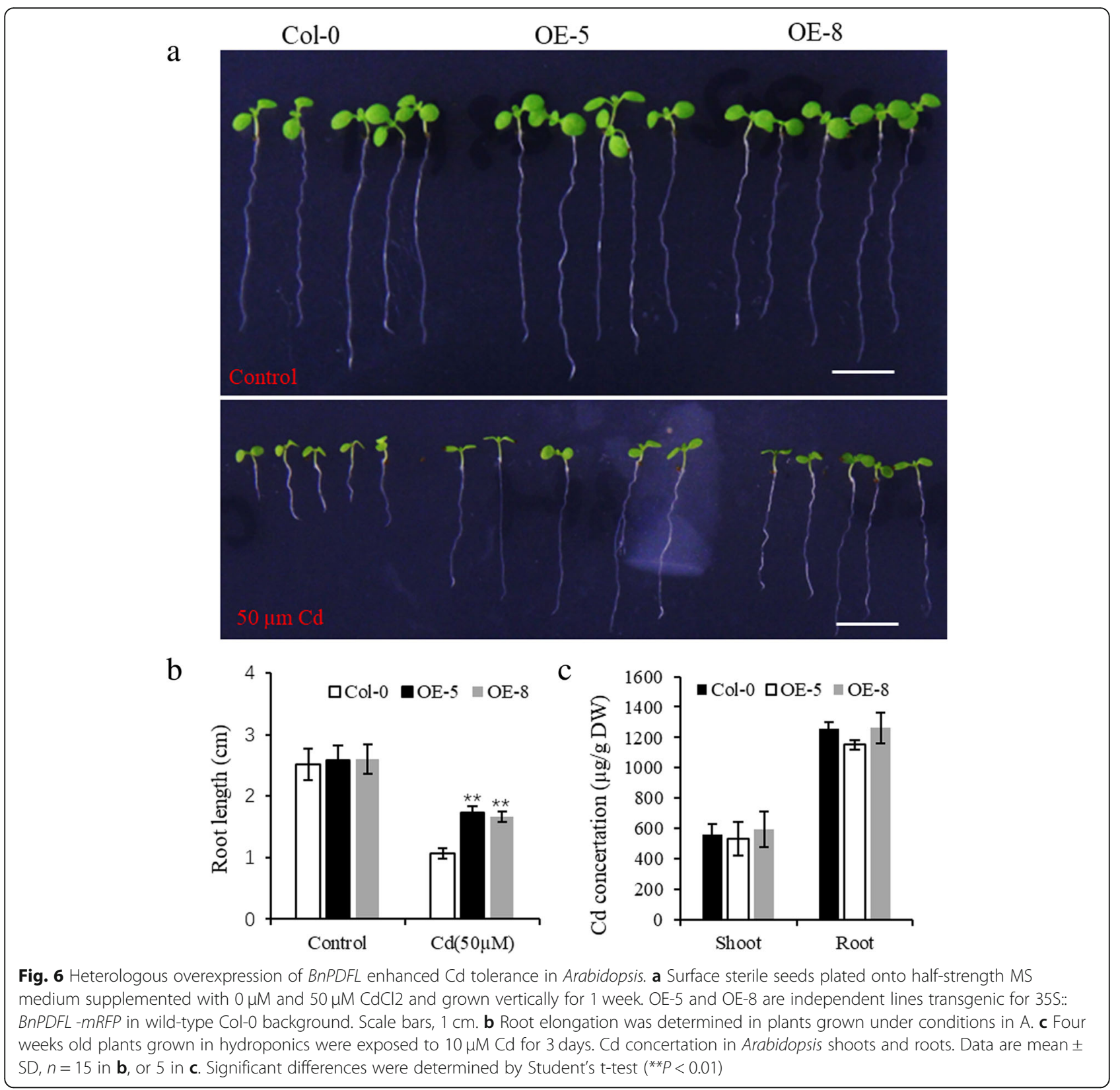

Arabidopsis [41]. The defensin-like family of proteins are small basic cysteine rich peptides that inhibit the growth of a broad range of fungi [42]; however, the zinc/Cdbinding activity of human defensin 5 has been reported [43], plant defensin type 1 genes (PDF1s) enhance zinc tolerance $[44,45]$, and our previous study revealed that plant defensin-like gene, CAL1, AtPDF2.5 and AtPDF2.6 mediates cadmium tolerance or accumulation [30-32]. We identified two defensin-like genes BnaA07g32150D and BnaC02g23620D in the xylem sap of Brassica napus (Fig. 4). Functional analysis indicated that BnaC02g 23620D (BnPDFL) had Cd-binding activity (Fig. 5a) and that heterologous overexpression of BnPDFL enhanced Cd tolerance in E. coli and Arabidopsis (Fig. $5 \mathrm{~b}, \mathrm{c})$. Functional disruption of the plant defensins AtPDF2.2 and AtPDF2.2 significantly decreased $\mathrm{Cd}$ tolerance in Arabidopsis (Fig. 6b, c). Based on our results, plant defensin plays an important role in $\mathrm{Cd}$ tolerance via chelation. The BnaA07g32150D protein was still detected in xylem sap when no $\mathrm{Cd}$ was added, indicating that it might have other functions and may act as a long-distance hormone-like signal to mediate stress responses, like hepcidin in humans, CLE25 or CEP [27, 29, 46]. 


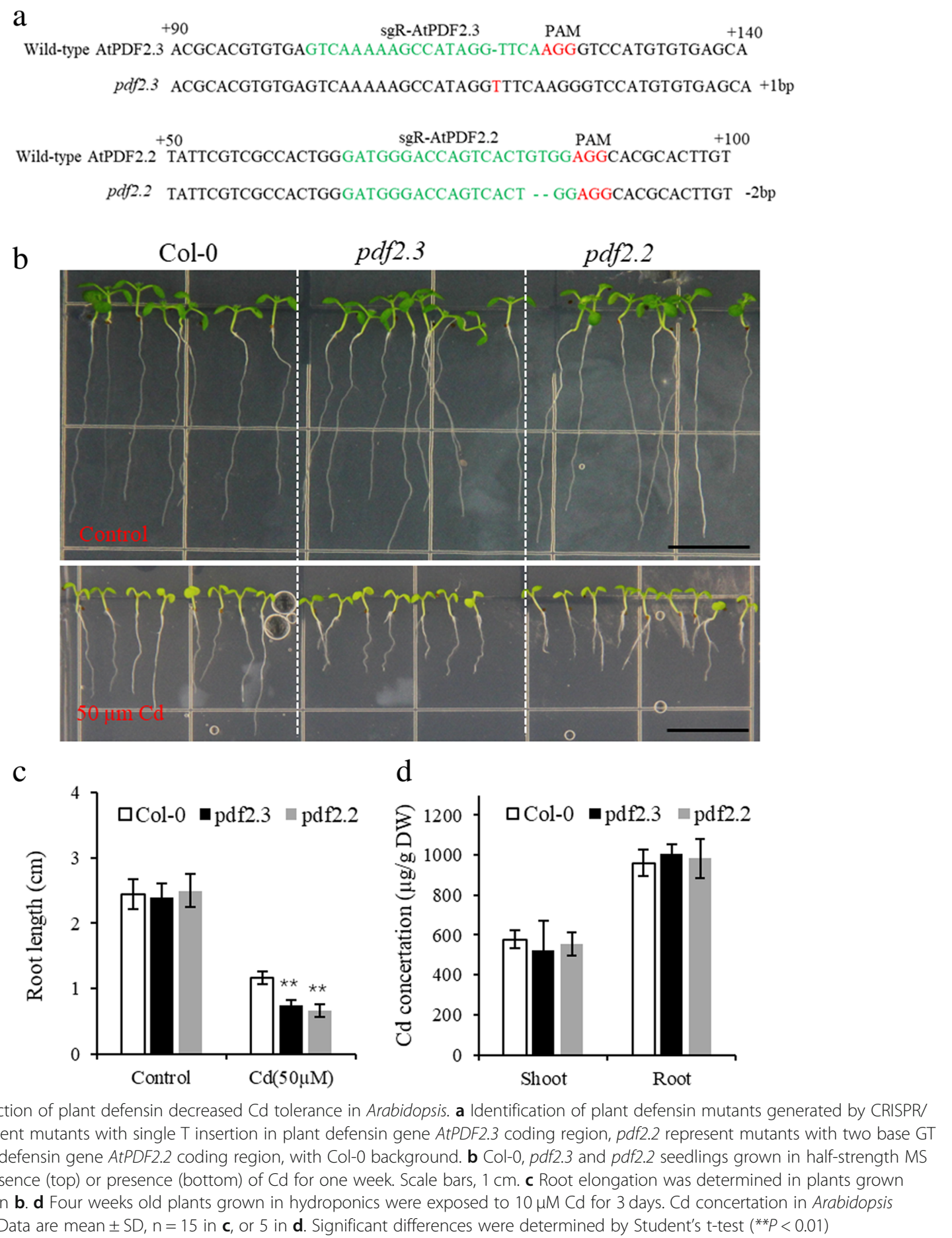

\section{Conclusions}

In summary, we identified and quantified 672 proteins in the xylem sap of Brassica napus; $67 \%$ were predicted to be secretory, and $11 \%$ (73 proteins) were unique to the Cd-treated samples. Cd stress caused statistically significant and biologically relevant abundance changes in
28 xylem sap proteins. Among these proteins, the metabolic pathways that were most affected were cell wall modifications, stress/oxidoreductases, and lipid and protein metabolism. We functionally validated defensin-like protein BnPDFL in xylem sap, which acts as a Cdbinding peptide. Our study identified a number of xylem 
sap proteins from Brassica napus that are differentially induced in response to $\mathrm{Cd}$ treatments and confirmed that plant defensins positively regulate $\mathrm{Cd}$ tolerance.

\section{Methods \\ Plant materials, xylem sap harvesting, and cd sensitivity analyses}

Brassica napus cultivar 'Xiang-you 15' ('XY15') was provided from colleagues, which contains abundant xylem sap for proteomic analysis. Arabidopsis mutants (pdf2.2 and $p d f 2.3$ ) and transgenic lines were generated in our laboratory. XY15 seedlings were hydroponically cultivated according to the method described by Han et al. [47]. At 2 weeks of age, the hydroponically grown Brassica napus seedlings were exposed to 0 (control) and $10 \mu \mathrm{M} \mathrm{Cd}$ (treatment) for 3 days, then xylem sap samples were collected. Briefly, stems were cut with a razor blade $2-3 \mathrm{~cm}$ above the basal stems to collect xylem sap for $2 \mathrm{~h}$. Xylem sap from the first $10 \mathrm{~min}$ was discarded to avoid contamination from damaged cells as described previously [25]. Xylem sap collected from 24 plants was pooled into one replicate, and a total of three replicates from 72 plants were used for each treatment. The xylem sap protein shotgun experiment was performed and analyzed by Shanghai Applied Protein Technology, Ltd. Leaf chlorophyll concentration was estimated using a SPAD 502 apparatus (Minolta Co., Osaka, Japan). The SPAD values of old expanded leaves were recorded at sampling time and an average per treatment was obtained. Arabidopsis thaliana plants were grown in quarter-strength hydroponic solution as described previously [48]. Seedling metal sensitivity assay were performed as described [32] with minor modification.

\section{Preparation of the protein samples for SDS-PAGE analysis and enzymolysis}

The xylem sap samples were concentrated under vacuo and lyophilized. A buffer $(200 \mu \mathrm{L}$ SDT 4\% SDS, $100 \mathrm{mM}$ Tris/ $\mathrm{HCl}, 0.1 \mathrm{M} \mathrm{DTT}$ ) was added to the lyophilized samples, treated with ice bath sonication, centrifuged at $4{ }^{\circ} \mathrm{C}$ and $14,000 \times g$ for $15 \mathrm{~min}$ and then the supernatant was collected. The Bradford assay method was used to measure protein concentration. We used SDS-PAGE on $20 \mu \mathrm{L}$ of the supernatant. Gels were stained with Coomassie Brilliant Blue. The filter aided proteome preparation method was used to carry out the trypsin enzymatic hydrolysis of each sample [49]. Samples were desalted using C18-SD Extraction Disk Cartridges, vacuum freeze-dried, dissolved in $0.1 \%$ formic acid, and quantified at OD280.

\section{Label free liquid chromatography-tandem mass spectrometry (LC-MS/MS)}

An HPLC liquid phase system Easy nLC was used to separate the proteins. Buffer A contained $0.1 \%$ formic acid, and buffer B contained $0.1 \%$ formic acid acetonitrile (acetonitrile was $84 \%$ ). The column was balanced with $95 \%$ buffer A. The samples were loaded into the Thermo Scientific EASY column $(2 \mathrm{~cm} \times 100 \mu \mathrm{M} 5 \mu \mathrm{m}-$ C18) using an automatic sampler, then separated in the analysis column Thermo scientific EASY column $(75 \mu \mathrm{m} \times 100 \mathrm{~mm} 3 \mu \mathrm{m}-\mathrm{C} 18)$ at a flow rate of $300 \mathrm{nl} /$ min. The liquid phase gradient was as follows: 0-100 min, buffer $\mathrm{B}$ from 0 to $50 \%$; $100-108 \mathrm{~min}$, buffer $\mathrm{B}$ from 50 to $100 \%$; $108-120 \mathrm{~min}$, buffer B fluid maintained at $100 \%$. The samples were detected using a QExactive mass spectrometer (Thermo Finnigan) after separation from the capillary high-performance liquid chromatography. The detection parameters were as follows: analysis time, $120 \mathrm{~min}$; detection methods, positive ions; mother ion scanning range, $300-1800 \mathrm{~m} / z$; level of mass spectrum resolution, 70,000 at $\mathrm{m} / z$ 200; AGC (Automatic gain control) target, 1e6; level of maximum IT, $50 \mathrm{~ms}$; number of scan ranges, 1; dynamic exclusion, $60.0 \mathrm{~s}$. The peptide and the peptide fragment chargemass ratios were determined according to the following methods: after every full scan, 10 pieces of the map (MS2 scan) were collected; MS2 Activation Type, HCD; isolation window, $2 \mathrm{~m} / z$; resolution of the secondary mass spectrometry, 17,500 at $\mathrm{m} / z$ 200; microscans, 1 ; secondary maximum IT, $60 \mathrm{~ms}$; normalized collision energy, $27 \mathrm{eV}$; Underfill ratio, $0.1 \%$.

\section{Mass spectrometry data and bioinformatics analysis}

The RAW file was retrieved from the client's database (uniport-Brassica_napus_62788_2018-04-13) using the Proteome Discoverer 1.4 software. The search parameters were set as follows: missed cleavage was set to 2; static decoration was set to Carbamidomethy C; dynamic modification was set to Oxidation $M$; peptide tolerance was set to $20 \mathrm{ppm}, \mathrm{ms} / \mathrm{ms}$ tolerance was set to $0.1 \mathrm{Da}$, peptide FDR was set to $<0.01$, protein FDR was set to < 0.01 . To assess the effect of $\mathrm{Cd}$ stress on the protein profile of tomato xylem sap, we calculated the ratio of normalized protein abundance in the Cd-treated and control samples. A volcano plot, showing the relationship between statistical significance $[-\log 10(p$-value $)]$ and biological significance [log2(fold-change)], was used to describe the changes induced by $\mathrm{Cd}$ treatment on the xylem sap proteome. Only changes with a $p \leq 0.05$ (ANOVA) and a normalized abundance ratio $\geq 2$ or $\leq 0.5$ were considered statistically significant and biologically relevant, respectively. Label-free quantification was used to determine protein relative content. 
Go function annotation of the identified proteins was carried out using BLAST2GO software. This process can be summarized as sequence alignment, mapping, annotation, and annotation augmentation. The presence of signal peptides in proteins was assessed using TargetP (www.cbs. dtu.dk/services/TargetP), and SecretomeP (www.cbs.dtu. $\mathrm{dk} /$ services/SecretomeP) was used to assign proteins as classical secretory (CS) and non-classical secretory (NCS) [50-52].

\section{DNA constructs and transformation into Arabidopsis}

A genomic fragment immediately upstream of the AtPDF2.2 (1385-bp) and AtPDF2.3 (962 bp) start codon were amplified with PCR using the primers ProAtPDF2.2 and ProAtPDF2.3, respectively (Additional file 8: Table S1). The resulting ProAtPDF2.2 and ProAtPDF2.3 promoter fragments were then sub-cloned into the binary vector pCAMBIA1300. To generate $p d f 2.2$ and $p d f 2.3$ mutants, the AtPDF2.2 and AtPDF2.3-specific guide RNA expression sequence was introduced into the CRISPR-Cas9 construct using primers sgR-AtPDF2.2 and sgR-AtPDF2.3, respectively (Additional file 8: Table S1), and the resulting 1300-bp fragment of Cas9 and AtPDF2.2 and AtPDF2.3-specific guide RNA expression cassettes were recovered by HindIII/EcoRI restriction digestion and sub-cloned into pCAMBIA1300 [53]. All the resulting constructs were transformed into Arabidopsis using the floral dip method [54]. Transgenic plants were screened using hygromycin B and confirmed by sequencing. To confirm the histological expression pattern of GUS driven by the proAtPDF2.2 and proAtPDF2.3 promoter, GUS histochemical staining was performed using a GUS histochemical assay kit (Real-Times, China) following the manufacturer's protocol.

\section{Subcellular localization, protein purification and related assay}

To determine the subcellular localization of BnPDFL in Arabidopsis, the 35S:: $m R F P$ fragment was recovered from 35S:: $m R F P /$ PA7 by HindIII/SacI restriction digestion, and the resulting 35S:: mRFP fragment was inserted into pCAMBIA1300 to generate the construct 35S:: mRFP/ pCAMBIA1300. The coding sequence of BnPDFL without a stop codon was PCR amplified using the primers OEBnPDF (Additional file 8: Table S1). The resulting fragment was fused in-frame to the $5^{\prime}$ terminus of mRFP to generate the constructs 35S::BnPDFL -mRFP/pCAMBIA130 as described [31], and transformed into Arabidopsis using the floral dip method [54].

Fragment of $\triangle$ SpBnPDFL (a truncated form of BnPDFL representing the mature BnPDFL protein from amino acids 26 to 85 ) was PCR amplified using the primers TF$\triangle$ SpBnPDFL (Additional file 8: Table S1) and cloned into the pCold-TF vector. Protein purification and related assay were performed as described previously [31]. The metal-to-protein stoichiometry was calculated according to the $\mathrm{Cd}$ and protein concentrations, as described previously [55]. $\triangle$ SpBnPDFL was also amplified by PCR using primers GST- $\triangle$ SpBnPDFL (Additional file 8: Table S1) and cloned into pGEX-2TK for metal sensitivity assays in E. coli as described previously [31].

\section{Statistical analysis}

Data were analyzed using two-tailed Student's $t$ tests, and differences were deemed significant at $P<0.05$ and extremely significant at $P<0.01$.

\section{Accession numbers}

Sequence data from this study can be found in the Arabidopsis Genome Initiative or GenBank/EMBL databases under the following accession numbers: AtPDF2.1 (At2g02120), AtPDF2.2(At2g02100), AtPDF2.3(At2g021 30), AtPDF2.4(At1g61070), AtPDF2.5(At5g63660), and AtPDF2.6(At2g02140). BnPDFL (BnaC02g23620D) and BnaA07g32150D sequence can be found in uniport database.

\section{Additional files}

Additional file 1: Figure S1. Simply Label free experiment design and analysis. (DOCX $370 \mathrm{~kb}$ )

Additional file 2: Figure S2. Subcellular localization prediction of the identified proteins. (DOCX $32 \mathrm{~kb}$ )

Additional file 3: Figure S3. Numbers of identified proteins in the control and Cd-treated samples. (DOCX $171 \mathrm{~kb}$ )

Additional file 4: Figure S4. Basic characteristics of proteins identified in Brassica napus xylem sap. (DOCX 391 kb)

Additional file 5: Figure S5. Bioinformatics analysis of BnPDFL. (DOCX $199 \mathrm{~kb}$ )

Additional file 6: Figure S6. BnPDFL is a Cell wall localized protein (DOCX $1838 \mathrm{~kb}$ )

Additional file 7: Figure S7. Histochemical localization of GUS activity in transgenic plants expressing the GUS reporter gene under the control of the proAtPDF2.3 or proAtPDF2.2 promoter. (DOCX $1753 \mathrm{~kb}$ )

Additional file 8: Table S1. Primers used in this study. (DOCX 104 kb)

\section{Abbreviations}

1/2MS: one-half Murashige and Skoog; AGC: Automatic gain control; Cd: Cadmium; Cd-\#: Cadmium-treated plant; CK-\#: control plant; CS: Classical secretory proteins; LC- MS/MS: liquid chromatography-tandem mass spectrometry; NCS: non-classical secretory; NS: non-secretory

\section{Acknowledgements}

We thank Can Peng (Core Facility, The Institute of Subtropical Agriculture, The Chinese Academy of Sciences) for helping with confocal microscopy.

\section{Authors' contributions}

JSL and ZHZ designed the experiments; JSL performed the experiments; JSL and $\mathrm{ZHZ}$ analyzed the data; and JSL and $\mathrm{ZHZ}$ wrote the manuscript. All authors read and approved the final manuscript.

\section{Funding}

This study was financially supported in part by the National Natural Science Foundation of China (31800202); Province Key R\&D Program of Hunan 
(2018NK1010); China Postdoctoral Science Foundation (2018 M630900); National Key R\&D Program of China (2017YFD0200100; 2017YFD0200103); Hunan Provincial Recruitment Program of Foreign Experts; and the National Oilseed Rape Production Technology System of China; "2011 Plan" supported by The Chinese Ministry of Education; Double First-Class Construction Project of Hunan Agricultural University (kxk201801005).

\section{Availability of data and materials}

The datasets used and/or analyzed during the current study are available from the corresponding author on reasonable request.

\section{Ethics approval and consent to participate}

Not applicable.

\section{Consent for publication}

Not applicable.

\section{Competing interests}

The authors declare that there are no conflicts of interest.

Received: 19 December 2018 Accepted: 19 June 2019

Published online: 26 June 2019

\section{References}

1. Bollard E. Transport in the xylem. Annu Rev Plant Physiol. 1960;11:141-66.

2. De Boer A, Volkov V. Logistics of water and salt transport through the plant: structure and functioning of the xylem. Plant Cell Environ. 2003;26:87-101.

3. Lucas WJ. Plant vascular biology and agriculture. J Integr Plant Biol. 2010;52: $4-7$.

4. Zimmermann MH. Long distance transport. Plant Physiol. 1974;54:472-9.

5. Kostner B, Schupp R, Schulze ED, Rennenberg H. Organic and inorganic sulfur transport in the xylem sap and the sulfur budget of Picea abies trees. Tree Physiol. 1998;18:1-9.

6. Kehr J, Buhtz A, Giavalisco P. Analysis of xylem sap proteins from Brassica napus. BMC Plant Biol. 2005:5:11.

7. Kudo T, Kiba T, Sakakibara H. Metabolism and long-distance translocation of cytokinins. J Integr Plant Biol. 2010;52:53-60.

8. Friedman $\mathrm{R}$, Levin N, Altman A. Presence and identification of polyamines in xylem and phloem exudates of plants. Plant Physiol. 1986;82:1154-7.

9. Biles CL, Abeles FB. Xylem sap proteins. Plant Physiol. 1991;96:597-601.

10. Satoh S, lizuka C, Kikuchi A, Nakamura N, Fujii T. Proteins and carbohydrates in xylem sap from squash root. Plant Cell Physiol. 1992;33:841-7.

11. Satoh S. Organic substances in xylem sap delivered to above-ground organs by the roots. J Plant Res. 2006;119:179-87.

12. Aki T, Shigyo M, Nakano R, Yoneyama T, Yanagisawa S. Nano scale proteomics revealed the presence of regulatory proteins including three FTlike proteins in phloem and xylem saps from rice. Plant Cell Physiol. 2008;49: 767-90.

13. Fisher DB. Long-distance transport. In: Buchanan B, Gruissem W, Jones R, editors. Biochemistry and Molecular Biology of Plants American Society of Plant Physiologists; 2000. p. 729-84

14. Young SA, Guo A, Guikema JA, White FF, Leach JE. Rice cationic peroxidase accumulates in xylem vessels during incompatible interactions with Xanthomonas oryzae pv oryzae. Plant Physiol. 1995;107:1333-41.

15. Buhtz A, Kolasa A, Arlt K, Walz C, Kehr J. Xylem sap protein composition is conserved among different plant species. Planta. 2004;219:610-8.

16. Ligat L, Lauber E, Albenne C, Clemente HS, Valot B, Zivy M, Pont-Lezica R, Arlat $\mathrm{M}$, Jamet $\mathrm{E}$. Analysis of the xylem sap proteome of Brassica oleracea reveals a high content in secreted proteins. Proteomics. 2011:11:1798-813.

17. Sakuta C, Satoh S. Vascular tissue-specific gene expression of xylem sap glycine-rich proteins in root and their localization in the walls of metaxylem vessels in cucumber. Plant Cell Physiol. 2000;41:627-38.

18. Oda Y, Fukuda H. Spatial organization of xylem cell walls by ROP GTPases and microtubule-associated proteins. Curr Opin Plant Biol. 2013;16:743-8.

19. Rep M, Dekker HL, Vossen JH, de Boer AD, Houterman PM, de Koster CG, Cornelissen BJC. A tomato xylem sap protein represents a new family of small cysteine-rich proteins with structural similarity to lipid transfer proteins. FEBS Lett. 2003:534:82-6.

20. Houterman PM, Speijer D, Dekker HL, DE Koster CG, Cornelissen BJC, Rep M. The mixed xylem sap proteome of fusarium oxysporum-infected tomato plants. Mol Plant Pathol. 2007:8:215-21.
21. Djordjevic MA, OakesM LDX, Hwang CH, Hocart CH, Gresshoff PM. The glycine max xylem sap and apoplast proteome. J Proteome Res. 2007;6: 3771-9.

22. Subramanian $\mathrm{S}, \mathrm{Cho} U-\mathrm{H}$, Keyes $\mathrm{C}, \mathrm{Yu} \mathrm{O}$. Distinct changes in soybean xylem sap proteome in response to pathogenic and symbiotic microbe interactions. BMC Plant Biol. 2009:9:119.

23. Alvarez S, Marsh EL, Schroeder SG, Schactman DP. Metabolomic and proteomic changes in the xylem sap of maize under drought. Plant Cell Environ. 2008;31:325-40.

24. Alvarez S, Goodger JQD, Marsh EL, Chen S, Asirvatham VS, Schachtman DP. Characterization of the maize xylem sap proteome. J Proteome Res. 2006;5: 963-72.

25. Ceballoslaita L, Gutierrezcarbonell E, Takahashi D, Abadía A, Uemura M, Abadía J, et al. Effects of Fe and Mn deficiencies on the protein profiles of tomato (solanum lycopersicum) xylem sap as revealed by shotgun analyses. J Proteome. 2017;170:117.

26. Liao C, Liu R, Zhang F, Li C, Li X. Nitrogen under- and over-supply induces distinct protein responses in maize xylem sap. J Integr Plant Biol. 2012;54(6):0-0.

27. Takahashi F, Suzuki T, Osakabe Y, Betsuyaku S, Kondo Y, Dohmae N, Fukuda $\mathrm{H}$, Yamaguchi-Shinozaki K, Shinozaki K. A small peptide modulates stomatal control via abscisic acid in long-distance signalling. Nature. 2018;556:235-8.

28. Ohkubo Y, Tanaka M, Tabata R, Ogawa-Ohnishi M, Matsubayashi Y. Shootto-root mobile polypeptides involved in systemic regulation of nitrogen acquisition. Nat Plants. 2017;3:17029.

29. Tabata R, Sumida K, Yoshii T, Ohyama K, Shinohara H, Matsubayashi Y. Perception of rootderived peptides by shoot LRR-RKs mediates systemic Ndemand signaling. Science. 2014;346:343-6.

30. Luo JS, Huang J, Zeng DL, Peng JS, Zhang GB, Ma HL, Guan Y, Yi HY, Fu YL, Han B, Lin HX, Qian Q, Gong JM. A defensin-like protein drives cadmium efflux and allocation in rice. Nat Commun. 2018:9:645.

31. Luo JS, Gu TY, Yang Y, Zhang ZH. A non-secreted plant defensin AtPDF2.6 conferred cadmium tolerance via its chelation in Arabidopsis. Plant Mol Biol. 2019. https://doi.org/10.1007/s11103-019-00878-y.

32. Luo JS, Yang Y, Gu TY, Wu Z, Zhang ZH. The Arabidopsis defensin gene AtPDF2.5 mediates cadmium tolerance and accumulation. Plant Cell Environ. 2019:1-15. https://doi.org/10.1111/pce 13592.

33. Loix C, Huybrechts M, Vangronsveld J, Gielen M, Keunen E, Cuypers A. Reciprocal interactions between cadmium-induced cell wall responses and oxidative stress in plants. Front Plant Sci. 2017.

34. Krzesłowska M. The cell wall in plant cell response to trace metals: polysaccharide remodeling and its role in defense strategy. Acta Physiol Plant. 2011;33:35-51.

35. Macmillan CP, Mansfield SD, Stachurski ZH, Evans R, Southerton SG. Fasciclin-like arabinogalactan proteins: specialization for stem biomechanics and cell wall architecture in arabidopsis and eucalyptus. Plant J. 2010;62: 689-703.

36. Ham BK, Li G, Kang BH, Zeng F, Lucas WJ. Overexpression of Arabidopsis plasmodesmata germin-like proteins disrupts root growth and development. Plant Cell. 2012;24:3630-48.

37. López-Millán AF, Morales F, Abadía A, Abadía J. Effects of iron deficiency on the composition of the leaf apoplastic fluid and xylem sap in sugar beet. Implications for iron and carbon transport. Plant Physiol. 2000;124:873-84.

38. Paniagua C, Bilkova A, Jackson P, Dabravolski S, Riber W, Didi V, Houser J, Gigli-Bisceglia N, Wimmerova M, Budínská E, Hamann T, Hejatko J. Dirigent proteins in plants: modulating cell wall metabolism during abiotic and biotic stress exposure. J Exp Bot. 2017;68:3287-301.

39. Cuypers A, Hendrix S, Amaral Dos Reis R, De Smet S, Deckers J, Gielen H, Jozefczak M, Loix C, Vercampt H, Vangronsveld J, Keunen E. Hydrogen peroxide, signaling in disguise during metal phytotoxicity. Front Plant Sci. 2016:7:470.

40. Chien PS, Nam HG, Chen YR. A salt-regulated peptide derived from the CAP superfamily protein negatively regulates salt-stress tolerance in Arabidopsis. J Exp Bot. 2015;66:5301-13.

41. Gong JM, Lee DA, Schroeder Jl. Long-distance root-to-shoot transport of phytochelatins and cadmium in Arabidopsis. Proc Natl Acad Sci U S A. 2003; 100:10118-23.

42. Thomma BP, Cammue BP, Thevissen K. Plant defensins. Planta. 2002;216: 193-202.

43. Zhang Y, Cougnon FB, Wanniarachch YA, Hayden JA, Nolan EM. Reduction of human defensin 5 affords a high-affinity zinc-chelating peptide. ACS Chem Biol. 2013;8:1907-11. 
44. Mirouze M, Sels J, Richard O, Czernic P, Loubet S, Jacquier A, Francois IE, Cammue BP, Lebrun M, Berthomieu P, Marques L. A putative novel role for plant defensins: a defensin from the zinc hyper-accumulating plant, Arabidopsis halleri, confers zinc tolerance. Plant J. 2006:47:329-42.

45. Shahzad Z, Ranwez V, Fizames C, Marquès L, Le Martret B, Alassimone J, Godé C, Lacombe E, Castillo T, Saumitou-Laprade P, Berthomieu P, Gosti F. Plant defensin type 1 (PDF1): protein promiscuity and expression variation within the Arabidopsis genus shed light on zinc tolerance acquisition in Arabidopsis halleri. New Phytol. 2013;200:820-33.

46. Hunter HN, Fulton DB, Ganz T, Vogel HJ. The solution structure of human hepcidin, a peptide hormone with antimicrobial activity that is involved in iron uptake and hereditary hemochromatosis. J Biol Chem. 2002;277:37597-603.

47. Han YL, Song HX, Liao Q, Yu Y, Jian SF, Lepo JE, Liu Q, Rong XM, Tian C, Zeng J, Guan CY, Ismail AM, Zhang ZH. Nitrogen use efficiency is mediated by vacuolar nitrate sequestration capacity in roots of Brassica napus. Plant Physiol. 2016;170:1684.

48. Arteca RN, Arteca JM. A novel method for growing Arabidopsis thaliana plants hydroponically. Physiol Plant. 2000;108:188-93.

49. Wiśniewski JR, Zougman A, Nagaraj N, Mann M. Universal sample preparation method for proteome analysis. Nat Methods. 2009;6:359-62.

50. Emanuelsson O, Brunak S, von Heijne G, Nielsen H. Locating proteins in the cell using TargetP, SignalP and related tools. Nat Protoc. 2007:2:953-71.

51. Bendtsen JD, Jensen LJ, Blom N, Von Heijne G, Brunak S. Feature-based prediction of non-classical and leaderless protein secretion. Protein Eng Des Sel. 2004;17:349-56.

52. Bendtsen JD, Kiemer L, Fausbøll A, Brunak S. Non-classical protein secretion in bacteria. BMC Microbiol. 2005;5:58.

53. Mao Y, Zhang H, Xu N, Zhang B, Gou F, Zhu JK. Application of the CRISPRCas system for efficient genome engineering in plants. Mol Plant. 2013;6: 2008-11.

54. Clough SJ, Bent AF. Floral dip: a simplified method for agrobacterium mediated transformation of Arabidopsis thaliana. Plant J. 1998;16:735-43.

55. Wan $\mathrm{X}$, Freisinger $\mathrm{E}$. The plant metallothionein 2 from Cicer arietinum forms a single metal-thiolate cluster. Metallomics. 2009;1:489-500.

\section{Publisher's Note}

Springer Nature remains neutral with regard to jurisdictional claims in published maps and institutional affiliations.

Ready to submit your research? Choose BMC and benefit from:

- fast, convenient online submission

- thorough peer review by experienced researchers in your field

- rapid publication on acceptance

- support for research data, including large and complex data types

- gold Open Access which fosters wider collaboration and increased citations

- maximum visibility for your research: over $100 \mathrm{M}$ website views per year

At $\mathrm{BMC}$, research is always in progress.

Learn more biomedcentral.com/submissions 